\title{
Measuring the unmeasurable? A method to quantify adoption of integrated pest management practices in temperate arable farming systems
}

Article

Accepted Version

Creissen, H., Jones, P., Tranter, R., Girling, R., Jess, S., Burnett, F., Gaffney, M., Thorne, F. and Kildea, S. (2019) Measuring the unmeasurable? A method to quantify adoption of integrated pest management practices in temperate arable farming systems. Pest Management Science, 75 (12). pp.

3144-3152. ISSN 1526-4998 doi:

https://doi.org/10.1002/ps.5428 Available at

https://centaur.reading.ac.uk/81514/

It is advisable to refer to the publisher's version if you intend to cite from the work. See Guidance on citing.

To link to this article DOI: http://dx.doi.org/10.1002/ps.5428

Publisher: Wiley

All outputs in CentAUR are protected by Intellectual Property Rights law, including copyright law. Copyright and IPR is retained by the creators or other copyright holders. Terms and conditions for use of this material are defined in the End User Agreement. 


\section{www.reading.ac.uk/centaur}

\section{CentAUR}

Central Archive at the University of Reading

Reading's research outputs online 


\section{Pest Management Science}

\section{Measuring the unmeasurable? A method to quantify adoption of Integrated Pest Management practices in temperate arable farming systems}

\begin{tabular}{|r|l|}
\hline Journal: & Pest Management Science \\
\hline Manuscript ID & PM-19-0057.R1 \\
\hline Wiley - Manuscript type: & Research Article \\
\hline Date Submitted by the & n/a \\
\hline Complete List of Authors: & $\begin{array}{l}\text { Creissen, Henry; Scotland's Rural College, Agriculture Department } \\
\text { Jones, Philip; University of Reading, Centre for Agricultural Strategy } \\
\text { Tranter, Richard; University of Reading, Centre for Agricultural Strategy } \\
\text { Girling, Robbie; University of Reading, Centre for Agri-Environmental } \\
\text { Research } \\
\text { Jess, Stephen; Agri-Food and Biosciences Institute for Northern Ireland, } \\
\text { Applied Plant Science } \\
\text { Burnett, Fiona; Scotland's Rural College, Agriculture Department } \\
\text { Gaffney, Michael; Teagasc, Horticultural Development Department } \\
\text { Thorne, Fiona; Teagasc, Agricultural Economics and Farm Surveys } \\
\text { Department } \\
\text { Kildea, Steven; Teagasc Crops Research Centre, Crop Production and } \\
\text { Protection }\end{array}$ \\
\hline Key Words: & $\begin{array}{l}\text { Integrated Pest Management, IPM scoring system, IPM metric, arable } \\
\text { farming, farmer survey, sustainable agriculture, National Action Plan, } \\
\text { Sustainable Use Directive, IPM uptake, IPM adoption }\end{array}$ \\
\hline
\end{tabular}

\section{SCHOLARONE Manuscripts}


1 Title: Measuring the unmeasurable? A method to quantify adoption of

2 Integrated Pest Management practices in temperate arable farming systems

3 Running title: Quantifying adoption of Integrated Pest Management in arable

4 farming

5 Henry E. Creissen a, b *, Philip J. Jones c, Richard B. Tranter c, Robbie D. Girling d,

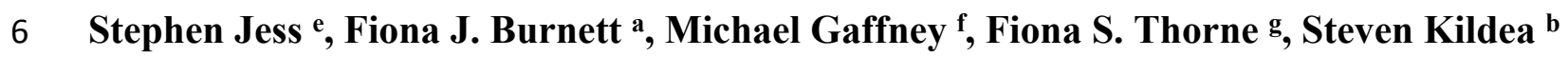

7 a Agriculture Department, Central Faculty, Scotland's Rural College, Edinburgh EH9 3JG, UK.

$8 \quad{ }^{b}$ Crop Science Department, Oak Park Crops Research Centre, Carlow, Ireland.

$9{ }^{\mathrm{c}}$ Centre for Agricultural Strategy, School of Agriculture, Policy and Development, University of 10 Reading, Reading RG6 6AR, UK.

$11{ }^{\mathrm{d}}$ Centre for Agri-Environmental Research, School of Agriculture, Policy and Development, University 12 of Reading, Reading RG6 6AR, UK.

13 e Agri-Food Sciences Division, Agri-Food and Biosciences Institute, 18a Newforge Lane, Belfast BT9 14 5PX, UK.

$15{ }^{\mathrm{f}}$ Horticultural Development Department, Teagasc, Ashtown, Dublin 15, Ireland.

$16 \mathrm{~g}$ Agricultural Economics and Farm Surveys Department, Teagasc, Ashtown, Dublin 15, Ireland.

17 *Corresponding author Email: henry.creissen@,sruc.ac.uk Phone: +44 1315354119 
19 Abstract

20

21

22

BACKGROUND: The impetus to adopt integrated pest management (IPM) practices has reemerged in the last decade, mainly as a result of legislative and environmental drivers. However a significant deficit exists in the ability to practically monitor and measure IPM adoption across arable farms; therefore the aim of the project reported here was to establish a universal metric for quantifying adoption of IPM in temperate arable farming. This was achieved by: (a) identifying a set of key activities that contribute to IPM; (b) weighting these in terms of their importance to the achievement of IPM using panels of expert stakeholders in order to create the metric (scoring system from 0-100 indicating level of IPM practiced); (c) surveying arable farmers in the UK and Ireland about their pest management practices; and (d) measuring level of farmer adoption of IPM using the new metric.

RESULTS. This new metric was found to be based on a consistent conception of IPM between countries and professional groups. The survey results showed that, while level of adoption of IPM practices varied over the sample, all farmers had adopted IPM to some extent (minimum 27.2 points, mean score of 65.1$)$, but only 13 of 225 farmers $(5.8 \%)$ had adopted more than $85 \%$ of what is theoretically possible, as measured by the new metric.

CONCLUSION. We believe that this new metric would be a viable and cost-effective system to use to facilitate the benchmarking and monitoring of national IPM programmes in temperate zone countries with large scale arable farming systems.

Keywords: Integrated Pest Management, IPM metric, IPM score, arable farming, farmer survey, sustainable agriculture. 


\section{Introduction}

41 Significant increases in crop production over the last century have resulted primarily from advancements in crop agronomy, including crop protection and nutrition, plant breeding and mechanisation of husbandry practices. These advances have largely been predicated on intensive use of inorganic chemical inputs, including fertilisers for plant nutrition and pesticides (collectively fungicides, herbicides, insecticides, molluscicides and nematicides) for crop protection. At the present time, commercial agriculture globally remains dependent on continued use of these synthetic crop protection products to prevent significant crop losses from pests. ${ }^{1}$ Furthermore, prophylactic application of pesticides has become common across many intensive crop production systems. ${ }^{2}$ However, input-intensive agriculture can and does

50 result in unwanted consequences, including, adverse impacts on human and environmental health, development of pesticide resistance, all of which potentially reduce the sustainability of these systems. ${ }^{3,4}$ With increasing awareness of these risks, there is now widespread acknowledgement for the need to move towards more sustainable methods of agricultural production. One such method, which was first proposed in the $1950 \mathrm{~s},{ }^{5}$ but that has gained significant traction and political support in recent years, is integrated pest management (IPM). IPM is regarded by many as a necessity for ensuring the optimum control of pests in an 57 economically and environmentally sustainable manner. ${ }^{5-10}$ Whilst the precise definition of IPM can vary between studies and stakeholders, ${ }^{11-13}$ it can broadly be categorised as an approach that considers the crop, the production system, the target pest(s) and their potential risks to 60 production, as a whole system. IPM simultaneously employs multiple pest-control solutions, 61 targeting different parts of this system, as a means to minimise the use of pesticides and ensure the long-term sustainability of pest control measures $10,14,15$. 
Whilst IPM can be readily understood in terms of such generalised statements and objectives, the diversity of pest control practices that exist across all scales of an individual production system makes identifying a definitive set of IPM practices extremely difficult. European Union Directive 2009/128/EC, on the sustainable use of pesticides, which requires each member state to encourage the use of IPM, identifies eight principles of IPM and a number of specific crop management activities within each. ${ }^{7}$ These eight principles (Table 1) have been further expanded upon by Barzman et al. ${ }^{10}$ to provide the basis from which IPM can be approached by all those involved in crop production. However, as Barzman et al..$^{10}$ concede, even with this level of specification, it is difficult to provide a definitive checklist of IPM practices, or even recommendations for approaches to implementing the eight principles. However, most commentators would agree that the over-arching principle must be preventing or suppressing the pest as opposed to intervening after the pest has become established, and that the implementation of each of the eight principles should involve a continual process of management plan redesign, implementation and evaluation. ${ }^{10,15}$ The perceived difficulties associated with quantifying adoption of IPM practices has influenced some countries, such as Denmark, to rely on pesticide usage as a proxy. In Denmark a pesticide tax system, which is based on the wider impacts of pesticide use, is employed in an attempt to encourage adoption of IPM practices. However, approaches to encourage adoption of IPM that rely heavily on a single measure, such as pesticide usage, do not account for differences in the need for pesticides between different cropping systems experiencing different pest challenges.

In arable farming there are a range of fairly ubiquitous crop management practices that are consistent with these eight principles of IPM, but which are simply understood as good husbandry. It is reasonable to assume, therefore, that most arable farmers may already be practicing some form of $\mathrm{IPM}^{16,17}$ even when they do not appreciate that fact. Arable famers tend to adopt IPM practices, in part, or incrementally over time by assessing the impacts of 
individual components and slowly building up to a fully integrated approach to pest control at which point complementarities between components occur. ${ }^{18,19}$ The practice of IPM, therefore, can be seen as a continuum, with some farmers further than others along that continuum to complete adoption. ${ }^{20}$ Previous attempts to establish a metric of IPM, which would allow for an assessment of where individual farmers lie on this continuum, have failed, largely due to the lack of an objective approach to assessing the relative importance of different IPM components and a lack of involvement of IPM practitioners in further pursuing the development of such a metric..$^{21-23}$

Before informed efforts to increase the adoption of IPM in arable production systems can be successfully implemented, accurate information on the current level of IPM practiced across a diversity of systems is required. To achieve this, it is a necessity to be able to place both individual farms and farm system typologies on some agreed metric of IPM. Such a metric requires two attributes: first, it must capture a core of IPM management activities, based on a consensus about what these are; and, second, the metric, must be able to use information on adoption of these activities to create a continuum of degree of IPM adoption. Hence, the IPM metric must be defined in terms of low-order, specific, actionable management activities. As such, it must be a compound measure, capturing multiple IPM management activities simultaneously.

The over-arching goal of this study therefore was to design and test a compound metric of IPM with sufficient flexibility to be applied to a variety of farm situations and with sufficient resolution to capture the continuum of degree of IPM adoption in a meaningful way. To reach this goal, the achievement of a number of sub-objectives are necessary: identify the main IPM activities that can be carried out on temperate arable farms; use stakeholder views to weight these activities based on their relative contribution to achieving IPM; construct a composite 
112 IPM measure based on these activities; test the efficacy of the IPM measure on a representative 113 sample of arable farms in England, Scotland, Northern Ireland and Ireland; validate the outputs 114 of the measure; and identify potential drivers of IPM involvement from among the 115 sociodemographic data collected from each participating farm business. Finally, some 116 conclusions are drawn of prime relevance to both practice and policy.

\section{Methods}

118 The study used a multi-stage process to achieve the objectives set out above, as outlined in 119 Figure 1; Tasks 1-3: design, optimisation and piloting of the data collection instrument; Task 120 4: data collection; Task 5-6: developing the IPM metric; Task 7: use, validation and secondary 121 analysis of the IPM metric.

\subsection{Design, piloting and optimisation of the farmer survey (Tasks 1-3)}

123 Following a review of the IPM literature, including the general principles of IPM as outlined 124 by the EU's Sustainable Use Directive 2009/128/EC (Table 1), a list of IPM practices 125 associated with temperate arable agriculture was identified. This list was then used to inform 126 the design of a farmer questionnaire to record level of involvement with IPM. The farmer 127 questionnaire consisted of three types of question, first, questions which captured information on farmer engagement with specific IPM activities; second, farm and farmer sociodemographic 129 information; and finally, information in farmer attitudes towards, and perceptions of, IPM. 130 Questions were a mix of: multiple choice, 5-point rating scales, and some open-ended questions, as appropriate to the type of information being elicited. The draft questionnaire was tested via two rounds of piloting with farmers, agronomists and arable researchers. Following the pilot, the number of questions was reduced from 44 to 22 by removing questions that proved

134 too complicated to answer fully, and combining questions to reduce repetition in the survey. 
135 The final questionnaire contained a total of 22 questions; nine questions relating to individual 136 IPM activities, based on the eight principles of IPM (Table 1), and a further five questions 137 relating to perceptions of IPM. The remaining eight questions collected sociodemographic 138 information (a copy of the questionnaire is available in Supplementary Materials; Appendix 1). 139 On average the questionnaire took 10-15 minutes to complete. To protect against any biases 140 that farmers may have concerning IPM, whether these be positive or negative, the survey was 141 described as addressing best pest management practice in arable farming generally, rather than 142 IPM specifically.

\section{$143 \quad$ 2.2. Farmer survey sampling strategy (Task 4)}

144 Arable farmers were selected for interview at random using national datasets as a sampling 145 frame in each of the four study countries. Each national research partner was set a target of 146 collecting 50 completed responses to ensure a sufficient number of responses for robust 147 statistical analysis within each country. All responses were collected between 2016 and 2017. 148 Data collection was by face-to-face interviews in England, Northern Ireland and Ireland, these 149 being carried out by experienced farm data recorders, while data collection in Scotland was by means of a postal questionnaire.

\subsection{Developing a metric for the adoption of IPM on temperate arable farms (Tasks 5-6)}

152 The raw data collected from the survey on levels of adoption of each of the activities contributing to IPM contained no indication of the relative importance of these individual activities towards IPM. This weighting information was derived from a panel of industry stakeholders, all of whom are actively involved in the practice of pest management in arable 156 crops, using a two-stage Delphi style approach. The Delphi technique uses data from a panel 157 of informed people and builds this data, using an iterative process, towards a consensus. The 
strength of the technique lies in the fact that at each iteration the stakeholders have the opportunity to amend their original judgements in light of the data and arguments supplied by others. ${ }^{24}$ In the first stage, a consultation with 11 stakeholders in Ireland was held in the form of a workshop (see Table 2 for details). At the workshop, stakeholders were given a guidance document (Supplementary material; Appendix 2) and a copy of the farmer questionnaire 163 (Supplementary material; Appendix 1) in addition to a verbal explanation of the project and the aims and structure of the meeting.

The stakeholders were then asked to weight each of the six pre-selected questions relating to adoption of IPM in the farmer questionnaire, on the basis of the importance of the pest management activity that it captured, for IPM as a whole. The weighting process was undertaken in two parts. First, where questions had sub-components, i.e. the question captured multiple activities of a certain type, stakeholders were asked to provide ranks on a 1-5 scale for these. The ranks were generated through an open discussion of the relative importance of each sub-component to the question as a whole. Discussion continued until a consensus was reached around a rank score. Second, each question was then awarded a weight based on its importance to IPM. This involved allocating a total of 100 points over all six questions to decide on the percentage contribution each question made to the overall IPM score. All six questions were then combined, after applying the appropriate question weights, and divided by five (each measure in the composite represents a 5-point scale) to form a composite Likert-type rating 177 scale ${ }^{25}$ with a 100-point range representing level of IPM uptake, i.e. the IPM score.

178 The provisional set of weights derived from this workshop were then presented to a larger stakeholder panel (see Table 2 and Table 3), by email and postal surveys across the study countries in late 2017. Stakeholders were targeted in attempt to gather responses from those actively involved in the practice of IPM. A total of 174 surveys were distributed and 46 
responses collected. The group of stakeholders were informed of the original provisional set of weights and then asked to provide their own estimate for each weight. To ensure consistency of approach between participants in these surveys, each was sent a guidance document, providing instructions for completing the questionnaire (Supplementary material; Appendix 3). A total of 46 responses were collected and weights collected used on a one vote per stakeholder basis. All data collected for this study, i.e. from the stakeholder workshop, and stakeholder and farmer surveys were transcribed into electronic datasets and checked for errors (survey data input file can be found in Supplementary material; Appendix 4). All statistical analyses of the survey data were undertaken using the data analytics package SAS version 9.4. ${ }^{27}$

\subsection{Validation and secondary analysis of the IPM metric (Task 7)}

A probability-probability plot was used to determine whether the distribution of the composite IPM variable was normal or otherwise before other statistical operations were performed. Cronbach's alpha was used to test for internal consistency in the composite IPM measure, by measuring the inter-correlation between items, where an Alpha score of $>0.7$ is assumed to indicate that the component questions cohere, i.e. they co-vary together.

To test the extent to which there is a common understanding of IPM between countries and subgroups of stakeholders, the weights awarded by these different stakeholder groups were compared. For the purposes of the analysis four different classes of stakeholder were identified: Farmers, Independent agronomists (defined as those who do not directly benefit financially from pesticide sales), Merchant agronomists, and Others. As degrees of freedom in some of these groups were low, t-test comparisons were performed with aggregated stakeholder groups, i.e. Farmer + Independent agronomist + Merchant agronomist compared with 'Other', where 'Other' represents researchers, agricultural college educators and policy makers. The rationale for dividing the stakeholders into these two groups is that the first group comprises those that 
206 have a commercial interest in pest management, whilst the 'Other' group are unlikely to have

207 such commercial interest.

208 To test for country understanding of IPM, an ANOVA was carried out to determine whether 209 stakeholders from the different countries applied different weights to the questions. For the 210 purposes of this analysis, Northern Ireland was combined with the data for Ireland due to low 211 observation numbers for Northern Ireland and the authors' perception of cultural and 212 agricultural similarities between the countries.

\section{Results}

214 3.1. The farmer survey sample

215 A total of 225 responses were collected for the farmer survey: Northern Ireland (71), Ireland 216 (58), England (53), Scotland (43) (Table 4). The majority of respondents to the survey were 217 owners of the farm businesses. Farms varied considerably in size between countries, with the 218 largest farms found in Scotland, with an average size of 362 ha, and the smallest in the Ireland, 219 with an average farm size of 101 ha. $67 \%$ of the land on farms in the England sample was 220 arable land, with the remainder being improved grassland. Land cover on farms in the other 221 countries was much more heterogeneous, with smaller percentages of arable land and more 222 grassland (Table 4).

223 3.2. The weighting of the components of the IPM metric

224 The final set of weights provided by stakeholders for each question is outlined in Table 5, 225 whilst the final weights for sub-elements within each question are available in Appendix 3 of 226 the supplementary material. Overall, the weights awarded by stakeholders at the workshop 227 differed from the final stakeholder weights by between $1.6 \%$ and $17.8 \%$ for all questions, with 
the exception of question 5, where the variation was $75.4 \%$. However, there was an inverse relationship between the absolute size of the weights and the percentage variation, with the bigger weights showing the smallest variation (Table 5). Question 8, which focussed on activities designed to prevent weeds, disease and insects/molluscs, was judged to account for $47 \%$ of the achievable IPM score, with factors influencing pest management plans (Question 9) coming in second, with a relative contribution of $15 \%$ to the IPM score.

\subsection{Validation of the IPM metric}

Farmers IPM scores were relatively normally distributed (Supplementary materials; Appendix 5) with a range of $27.2-91.3$, a mean of 65.1 and a standard deviation of 13.8 (Coefficient of Variation 21\%), i.e. exhibiting a normal bell-shaped curve, although the distribution is somewhat skewed towards higher IPM scores (Figure 2), suggesting that the majority of farmers are already implementing at least some measures that would be seen as characteristic of IPM. However, while all farmers are practicing some of level of IPM, only 13 out of 225 farmers $(5.8 \%)$ scored more than 85 on a possible scale of 100 . Any responses containing a high amount of unanswered questions, leading to a score of less than 20 , would have been removed from the survey but none of our respondents fell into that category.

\subsection{The coherence of the IPM metric}

Cronbach's Alpha was used to test the coherence of the questions combined, after weighting, to create the IPM metric. There are no hard and fast rules about what Alpha value is required to show adequate coherence in the sets of measures used to form composites, but it is widely held that the higher the value the better (although extremely high values might be suggestive of redundancy among the measures). A precedent has become established that Cronbach's 
251 Alpha values in excess of 0.7 are classed as good or better, so this convention and threshold 252 has been followed here. ${ }^{26}$ When undertaking this testing of the internal consistency of the 253 composite IPM measure, the three components of Question 8, relating to the choice of pest 254 prevention measures, were separately tested for coherence. Each of these three questions, a) 255 measures for prevention of weeds; b) measures to prevent diseases; and c) measures to prevent 256 insect pests/nematodes/molluscs, was itself a composite measure, made up of a number of sub257 components. With the exception of Question $8 \mathrm{~b}$ - 'What measures are used to control diseases', 258 all questions had a Cronbach's Alpha $>0.7$ (Table 6) strongly suggesting that these composite 259 questions were also coherent. Question $8 \mathrm{~b}$ had a Cronbach's Alpha of 0.68 . While obviously 260 falling below the 0.7 threshold set above, the literature suggests that this value is still 261 acceptable. ${ }^{26}$ Overall these results suggest a high degree of internal consistency in the 262 composite IPM measure.

\section{$263 \quad 3.5 \quad$ A consensus as to what constitutes IPM practice across groups and countries}

264 For four of the six questions, there were no significant differences in the weights attributed by 265 the two stakeholder consultation classes (Table 7). This lack of significant difference between 266 the weights awarded by the two stakeholder classes indicates that there was a consensus on 267 what constitutes IPM practice. For two questions, there were significant differences between 268 the two stakeholder classes; Q5 - 'What influences your choice of cereal variety?', and Q14 269 'Membership of an agronomy/crop discussion group'. However, these two questions only 270 account for, a combined weight of, $14.6 \%$ of the overall IPM score. In both instances, those 271 stakeholders with commercial interest in pest management (farmers and agronomists) weighted

272 the questions higher in importance than those stakeholders that are commonly considered to 273 have no commercial interest (researchers, regulators, educators), with Q5 seeing a 69\% 274 increase in weight and Q14 a 78\% increase. 
275 No statistically significant differences amongst countries in the weights applied by stakeholders 276 to any of the IPM questions were identified (Table 8). In the case of Q4 - 'Why do you typically 277 use an arable rotation?' differences were close to being significant $(\mathrm{P}=0.07)$, but this is a 278 question with a relatively small weighting. The national differences in weight on this question 279 occurred between England (12.1\%) and Scotland (9.9\%), and also the island of Ireland (14.0\%) 280 and Scotland.

\section{Discussion and conclusion}

282 IPM is a knowledge-intensive process in which scientifically proven measures are selected for 283 use, based on the specific set of biotic threats affecting the crop and the financially viable 284 approaches available to the grower, to reduce risk associated with these threats. ${ }^{10,28}$ As such IPM does not necessarily rely upon individual control mechanisms in isolation but seeks to use a complexity of inter-related strategies. It is this complexity that makes capturing levels of IPM practiced at the farm scale difficult. This difficulty can be further compounded by unintentional perspective bias, for example relating to what does and does not constitute an IPM activity, imposed by observers via both the methods used to collect such data and the assessment process. ${ }^{23}$ Such bias can result in the exclusion of activities which legitimately contribute to IPM being from the survey and other IPM activities being attributed irrational weights.

The development of a metric to assess the extent of adoption of IPM described here differs in approach from those currently in existence. This is because the generation of the weighting system for the various elements of IPM was, in this case, rigorous, and involved a number of IPM practitioners from various professional backgrounds. Many previous attempts to develop such a metric have not been able to garner widespread support due to the fact that the process of determining which activities to include in the metric and the weights attributable to these

298 has remained solely in the hands of researchers, with little or no reference to industry 
299

300

301

302

303

304

305

306

307

308

309

310

311

312

313

314

315

316

317

318

319

320

321

322

323

stakeholders such as farmers and professional agronomists. ${ }^{21-23}$ The carefully controlled approach to developing a metric for IPM reported here, together with the observed clear withinsector and between-country consensus about what constitutes IPM suggests that this IPM metric has potential for use in an international context.

Currently, gaps exist between farmer perception of the value of IPM and their actual practice. Whereas farmer attitudes towards IPM are often positive, the practicalities and perceived financial implications associated with IPM adoption can act as barriers. ${ }^{29,30}$ Gaps may also exist between actual and perceived practices i.e. farmers may believe they are practicing IPM when in reality they are not, and vice versa. ${ }^{16,31}$ Such a phenomenon may have contributed to differences between weightings awarded to certain questions at the workshop, and then later at the stakeholder survey. Whilst the perceived importance of the majority of questions as contributors to IPM were not viewed differently amongst the different stakeholder groups, differences did exist for perceived importance of some of the lesser contributors, i.e. factors influencing variety choice and membership of discussion groups. Likewise, with the exception of the question relating to cereal rotations (Question 4), stakeholders from the different countries ranked questions in equal importance. Stakeholders from the island of Ireland and England considered the question on rotations to be relatively more important for IPM than did stakeholders from Scotland. This could be due to the dominance of spring barley in the Scottish arable sector. With a single, premium crop dominating the market, alternative suitable cropping options are potentially reduced and, thus, growing different crops in rotation may not be considered a viable option. Regarding the other differences between the two stakeholder groups, those stakeholders who have a commercial interest in pest management weighted discussion group membership as being more important for IPM than the stakeholder group who are unlikely to have a commercial interest in pest management. This indicates that they recognise a greater value in this form of knowledge exchange which may lead to an increase 
324 in adoption of IPM practices. There were also differences in the weights awarded to the 325 question on varietal selection, with stakeholders who have a commercial interest in pest 326 management weighting the question more important for IPM. Selecting varieties based on their 327 disease resistance rating, in particular, has long been promoted as a major tool for disease management. Scottish barley growers have claimed to select and grow disease resistant varieties, yet on consulting the Agriculture and Horticulture Development Board (AHDB) disease resistance ratings, the varieties grown are often rated much weaker than others for the major disease threats such as rhynchosporium. ${ }^{31}$ This finding was mirrored in the survey of UK growers undertaken by ADAS consulting limited. ${ }^{16}$ The lower weighting awarded to this question at our expert workshop could have been, in part, due to discussions involving stakeholders in Ireland who may consider themselves restricted in their choice of varieties due to a lack of suitability of commercial cultivars to Irish growing conditions owing to an absence of cereal breeding programmes in Ireland. The fact that these differences were not observed when investigating differences in weighting between the stakeholders from different countries may suggest that this may, in fact, be an artefact of the consultation method. As such only the aggregate score from the survey panel of stakeholders was used in the creation of the IPM metric.

341 By combining the targeted survey of arable farms with a stratified sampling method and the 342 consensual development of a metric to capture IPM in arable production systems, it is 343 anticipated that current levels of IPM adoption, and perception of it, in both the UK and Ireland 344 can be determined and if the survey were to be repeated changes in adoption could be tracked. 345 If the barriers or, indeed, the limitations of IPM in such systems are to be identified, this is a 346 key step in the process. Although all respondents were considered to be practicing IPM (of the 347225 respondents all scored $>20$ of a total score of 100), a wide range of scores within a broadly 348 normal distribution was recorded. This distribution opens the possibility of identifying such 
349 barriers/limitations to further adoption. This process could be further enhanced by including, 350 in subsequent analysis of drivers and barriers, various questions relating to IPM perception 351 and/or socioeconomic data. As the data set obtained for both Ireland and England contained 352 official national farm business survey statistics, it may also be possible to delve further into 353 financial components of the farm enterprise that may directly or indirectly influence IPM 354 practice.

355 The applicability of the metric to arable farming in other temperate zone countries is as yet, 356 unknown. However, it is foreseeable that the metric and the phenomena it captures will be 357 relevant elsewhere. Using the approach reported here, modification of the metric, by re358 weighting questions based on expert opinion, according to the challenges and opportunities for 359 IPM in each country, may render the metric widely applicable. This would result in a locally360 weighted IPM metric approach. Furthermore, the process by which the survey and metric were 361 developed can be easily adapted to cover additional crops and cropping systems requiring 362 different approaches to pest control.

363 Despite a considerable body of legislation relating to pesticide practice and use, both nationally 364 and at EU level, there has been, to date, no agreed upon metric available that would allow the 365 measurement of the effectiveness of IPM at reducing pesticide usage or increasing adoption of 366 sustainable crop protection methods. The study reported here provides a novel and useful 367 metric to assess the extent of adoption of IPM practices and the possible development of a 368 sustainable plant protection system for arable cropping in temperate climates.

\section{$\underline{\text { Acknowledgements }}$}


371 We acknowledge the financial and logistical support of the: Scottish Government Strategic 372 Research Programme; Rural Business Research (England); Department of Agriculture, Food 373 and the Marine (Ireland) (RSF 14/S/879); and the Department of Agriculture, Environment and 374 Rural Affairs (Northern Ireland) in enabling the research reported here. We thank all who 375 contributed to the design of the survey and all involved in data collection processes including 376 the Teagasc National Farm Survey recorders, Farm Business Survey recorders, Science and 377 Advice for Scottish Agriculture, Census and Single Farm Payment data recorders. We also 378 thank the stakeholders involved in developing the IPM metric and all the farmers who 379 participated in the survey. 
380

381

382

383

384

385

386

387

388

389

390

391

392

393

394

395

396

397

398

399

400

401

402

403

404

405

406

\section{References}

1 Oerke E, Crop losses to pests. The Journal of Agricultural Science 144:31-43 (2006).

2 Cooper J, Dobson H, The benefits of pesticides to mankind and the environment. Crop Prot. 26:1337-1348 (2007).

3 Goulson D, Thomson J, Croombs A, Rapid rise in toxic load for bees revealed by analysis of pesticide use in Great Britain. PeerJ 6:e5255 (2018).

4 Lamichhane JR, Dachbrodt-Saaydeh S, Kudsk P, Messean A, Toward a reduced reliance on conventional pesticides in European agriculture. Plant Dis. 100:10-24 (2016).

5 Stern V, Smith R, van den Bosch R, Hagen K, The integrated control concept. Hilgardia 29:81$101(1959)$.

6 European Union, Directive 2009/127/EC of the European Parliament and of the Council of 21 October 2009 amending Directive 2006/42/EC with regard to machinery for pesticide application. Official Journal of the European Union 52: 29-33 (2009a).

7 European Union, Directive 2009/128/EC of the European parliament and of the council of 21 October 2009 establishing a framework for community action to achieve the sustainable use of pesticides. Official Journal of the European Union 52:71-86 (2009b).

8 European Union, Regulation (EC) No 1107/2009 of the European parliament and of the council of 21 October 2009 concerning the placing of plant protection products on the market and repealing council directives 79/117/EEC and 91/414/EEC. Official Journal of the European Union 52:1-50 (2009c).

9 European Union, Regulation (EC) No 1185/2009 of the European Parliament and of the Council of 25 November 2009 concerning statistics on pesticides. Official Journal of the European Union 52:1-22. (2009d).

10 Barzman M, Barberi P, Birch ANE, Boonekamp P, Dachbrodt-Saaydeh S, Eight principles of integrated pest management. Agron. Sustainable Dev. 35:1199-1215 (2015).

11 Prokopy R., Kogan. M., 2003. Integrated pest management, in Encyclopedia of Insects, ed. by Resh VH and Carde RT. Academic Press, San Diego, pp. 589-595 (2003). 
40712 Kogan M, Bajwa WI, Integrated pest management: A global reality? An. Soc. Entomol. Bras. $408 \quad 28: 1-25(1999)$.

40913 Jeger M, Bottlenecks in IPM. Crop Prot. 19:787-792 (2000).

41014 Kogan $\mathrm{M}$, Integrated pest management: Historical perspectives and contemporary 411 developments. Annu. Rev. Entomol. 43:243-270 (1998).

41215 Ehler LE, Integrated pest management (IPM): Definition, historical development and 413 implementation, and the other IPM. Pest Manage. Sci. 62:787-789 (2006).

41416 ADAS, The Awareness, Use and Promotion of Integrated Crop \& Pest Management Amongst 415 Farmers and Growers, a Survey on Behalf of DEFRA and the CPA (2002).

416 Doonan H, Adoption of Integrated Pest Management in the UK arable sector. Outlooks Pest 417 Manage. 28:29-32 (2017).

41818 Lamine C, Transition pathways towards a robust ecologization of agriculture and the need for 419 system redesign cases from organic farming and IPM. Journal of Rural Studies 27:209-219 (2011). 19 Zepeda JF, Barreto-Triana N, Falck-Zepeda J, Barreto-Triana N, Baquero-Haeberlin I, Espitia-

Malagón E, Fierro-Guzmán H, López N, An exploration of the potential benefits of integrated

pestmanagement systems and the use of insect resistant potatoes to control the Guatemalan tuber moth (Tecia solanivora Povolny) in Ventaquemada, Colombia. International Food Policy Research Institute, Washington, DC (2006).

20 Benbrook CM, Groth E, Halloran JM, Hansen M, Marquardt S, Pest management at the crossroads. Consumers Union, Yonkers, NY, 272 pp (1996).

21 Shennan C, Cecchettini CL, Goldman GB, Zalom FG, Profiles of California farmers by degree of IPM use as indicated by self descriptions in a phone survey. Agric., Ecosyst. Environ. 84:267275 (2001).

22 Robertson MJ, Zehnder GW, Hamming MD, Adoption of integrated pest management practices in South Carolina cotton growers. Journal of Extension 43 (2005).

23 Puente M, Darnall N, Forkner RE, Assessing Integrated Pest Management Adoption: Measurement Problems and Policy Implications. Environ. Manage. 48:1013-1023 (2011). 
43424 Hsu CC, Sandford BA, The Delphi technique: making sense of consensus. Practical Assessment. $435 \quad$ Research and Evaluation 12: 1-8 (2007).

43625 Likert R, A technique for the measurement of attitudes. Archives of Psychology 140: 1-55 (1932).

43726 Taber KS, The use of Cronbach's alpha when developing and reporting research instruments in $438 \quad$ science education. Research in Science Education, 48(6), 1273-1296. (2018).

43927 SAS Institute Inc., Cary, North Carolina, USA.

44028 Byerlee D, Modern varieties, productivity, and sustainability—recent experience and emerging $441 \quad$ challenges. World Development 24:697-718 (1996).

44229 Sherman J, Gent D, Concepts of sustainability, motivations for pest management approaches, 443 and implications for communicating change. Plant Dis. 98:1024-1035 (2014).

44430 Royle DJ, Shaw MW, The costs and benefits of disease forecasting in farming practice. in: 445 Control of Plant Diseases: Costs and Benefits. eds. by Clifford BC and Lester E, Blackwell 446 Scientific Publications, London. Pp. 233-236 (1988).

44731 Stetkiewicz S, Bruce A, Burnett FJ, Ennos RA, Topp CFE, Perception vs practice: Farmer $448 \quad$ attitudes towards and adoption of IPM in Scottish spring barley. Crop Prot. 112:96-102 (2018) 
Table 1: The eight principles of IPM and their components as defined by the European Union, (2009b) and expanded by Barzmann et al. (2015). Also, the alignment of questions from the study questionnaire with each principle.

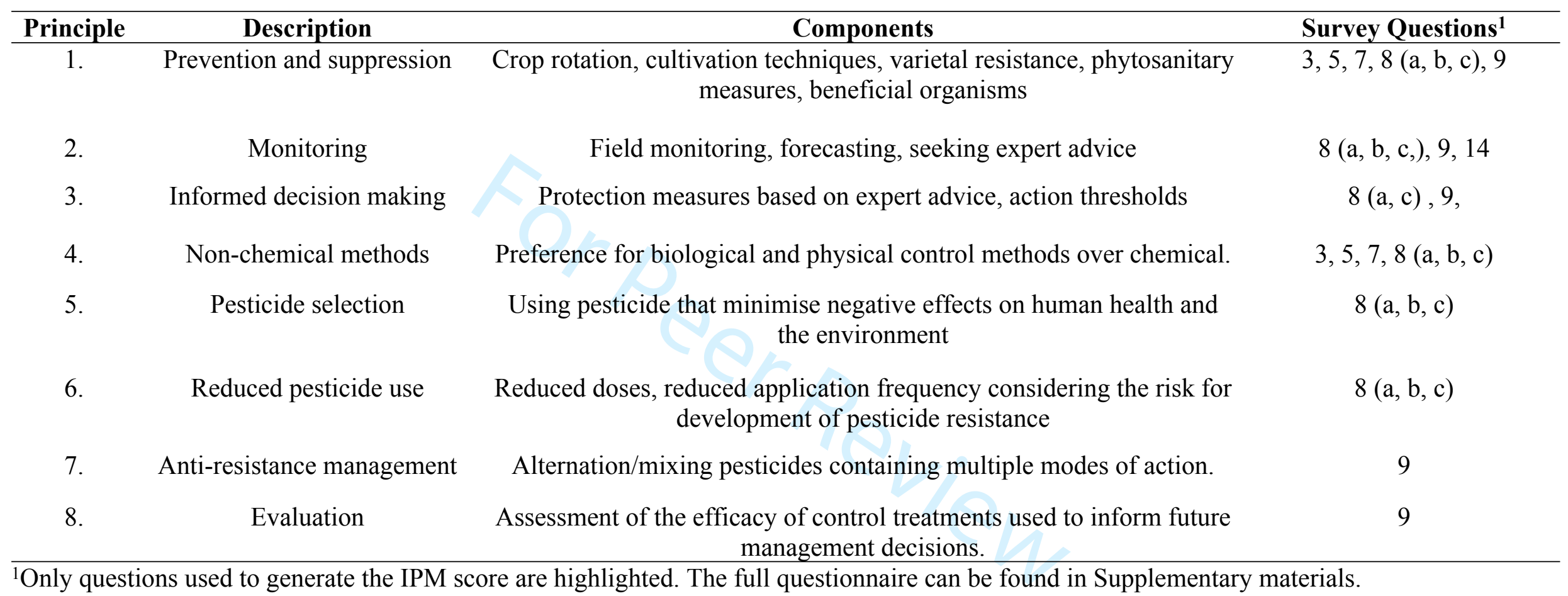


Table 2: Number of participants in the initial stakeholder workshop and subsequent stakeholder consultation panel, their principal occupation and their stakeholder class.

${ }^{1}$ Stakeholder workshop held on June $27^{\text {th }} 2017$ at Teagasc Oak Park, Ireland.

\begin{tabular}{lccc}
\hline Principal Occupation & $\begin{array}{c}\text { Stakeholder } \\
\text { Workshop }^{\mathbf{1}}\end{array}$ & $\begin{array}{c}\text { Stakeholder } \\
\text { Panel }^{\mathbf{2}}\end{array}$ & $\begin{array}{c}\text { Stakeholder class for } \\
\text { weighting analysis }^{\text {Former }}\end{array}$ \\
\hline Farmer & 2 & 18 & $\begin{array}{c}\text { Farmen } \\
\text { Independent Agronomist }\end{array}$ \\
Merchant agronomist & 1 & 11 & Merchant agronomist \\
Researcher & 5 & 8 & Other \\
Agricultural college lecturer & 0 & 0 & Other \\
Agricultural Regulator & 1 & 9 & Other \\
Total & 11 & 0 & \\
& & 46 & \\
\hline
\end{tabular}

${ }^{2}$ Stakeholder panel completing the survey from which the final weighting were derived.

Table 3: Number of stakeholder panel participants from each country involved in construction of the IPM metric.

\begin{tabular}{lc}
\hline Country & Participants \\
\hline England & 11 \\
Ireland & 12 \\
Northern Ireland & 4 \\
Scotland & 19 \\
\hline
\end{tabular}


Table 4: Overview of respondents to the survey and means of data collection in each of the participating countries.

\begin{tabular}{lcccc}
\hline & England & Scotland & $\begin{array}{c}\text { Northern } \\
\text { Ireland }\end{array}$ & $\begin{array}{c}\text { Republic of } \\
\text { Ireland }\end{array}$ \\
\hline Method of data collection & $\begin{array}{c}\text { Farm Business } \\
\text { Survey } \\
\text { recorders }\end{array}$ & Postal & $\begin{array}{c}\text { Census and } \\
\text { Single Farm } \\
\text { Payment data } \\
\text { recorders }\end{array}$ & $\begin{array}{c}\text { Teagasc } \\
\text { National } \\
\text { Farm Survey } \\
\text { recorders }\end{array}$ \\
Sample size & 53 & 43 & 71 & 58 \\
Percent owned & 54.6 & 83.7 & 97.2 & 68.6 \\
$\begin{array}{l}\text { Farm size (ha) } \\
\text { Of which arable (ha) }\end{array}$ & 202.19 & 361.5 & 109.2 & 101.07 \\
& 135.32 & 198.2 & 59.1 & 63.6 \\
\hline
\end{tabular}


Table 5: Relative contribution of each question (\% weight) awarded by stakeholders at the workshop ( $\mathrm{n}=11)$, the survey panel ( $\mathrm{n}=46)$, and the final combined set.

\begin{tabular}{|c|c|c|c|}
\hline Specific question within the survey & $\begin{array}{c}\text { Weights produced at } \\
\text { workshop }\end{array}$ & $\begin{array}{l}\text { Final set of weights } \\
\text { (produced by survey } \\
\text { panel) }\end{array}$ & $\begin{array}{c}\text { Variation from the } \\
\text { workshop weights }(\%)\end{array}$ \\
\hline Q3. Proportion of land in continuous cereal production & 10 & 11.46 & 14.6 \\
\hline Q4. Why do you typically use an arable rotation? & 10 & 11.78 & 17.8 \\
\hline Q5. What influences your choice of cereals variety? & 5 & 8.77 & 75.4 \\
\hline $\begin{array}{l}\text { Q8. What preventive measures are used to control weeds, } \\
\text { disease and insects/molluscs? }\end{array}$ & 55 & 46.93 & 14.7 \\
\hline $\begin{array}{l}\text { Q9. What factors do you consider when deciding on your pest } \\
\text { management plan? }\end{array}$ & 15 & 15.24 & 1.6 \\
\hline Q14. Membership of an agronomy / crop discussion group? & 5 & 5.82 & 16.4 \\
\hline Total & 100 & 100 & \\
\hline
\end{tabular}


Table 6: Correlation of component questions with overall IPM score and Cronbach's Alpha test.

\begin{tabular}{lcc}
\hline Specific question within the survey & $\begin{array}{c}\text { Correlation with total } \\
\text { (standardised scores) }\end{array}$ & $\begin{array}{c}\text { Alpha } \\
\end{array}$ \\
\hline Q3. What proportion of land on your farm is in continuous cereals production? & 0.412456 & 0.720713 \\
Q4. Why do you typically use an arable rotation? & 0.395048 & 0.724010 \\
Q5. What influences your choice of crop variety? & 0.407890 & 0.721580 \\
Q8a. What preventive measures are used to control weeds & 0.500479 & 0.703677 \\
Q8b. What preventive measures are used to control diseases & 0.602404 & 0.683182 \\
Q8c. What preventive measures are used to control insects & 0.471783 & 0.709298 \\
Q9. What factors do you consider when deciding on your pest management plan? & 0.362842 & 0.730049 \\
Q14. Membership of an agronomy / crop discussion group? & 0.343871 & 0.733569 \\
\hline
\end{tabular}

${ }^{1}$ High Alpha scores $(>0.7)$ for a specific question indicate a high correlation of that question with the overall score. 
Table 7: Impact of stakeholder occupations on the specific weighting for each of the identified questions relating to IPM practice.

\begin{tabular}{|c|c|c|c|c|}
\hline Specific question within the survey & $\begin{array}{c}\text { Difference } \\
\text { between groups }{ }^{1}\end{array}$ & T value & Variances & $\operatorname{Pr}>\mathbf{T}$ \\
\hline Q5. What influences your choice of crop variety? & 2.9339 & 1.71 & Unequal & 0.0130 \\
\hline $\begin{array}{l}\text { Q8. What preventive measures are used to control weeds, } \\
\text { disease and insects/molluscs? }\end{array}$ & -4.6727 & -1.16 & Equal & 0.2522 \\
\hline $\begin{array}{l}\text { Q9. What factors do you consider when deciding on your pest } \\
\text { management plan? }\end{array}$ & 0.3784 & 0.25 & Equal & 0.8070 \\
\hline Q14. Membership of an agronomy / crop discussion group? & 1.3303 & 1.71 & Unequal & 0.0041 \\
\hline
\end{tabular}


Table 8: Impact of stakeholder country of origin on the specific weighting awarded for each of the identified questions relating to IPM practice.

\begin{tabular}{lccc}
\hline Specific question within the survey & F value & Pr > F & R-Square \\
\hline Q3. What proportion of land on your farm is in continuous cereals production? & 0.90 & 0.4128 & 0.040318 \\
Q4. Why do you typically use an arable rotation? & 2.76 & 0.0743 & 0.113889 \\
Q5. What influences your choice of crop variety? & 0.78 & 0.4631 \\
$\begin{array}{l}\text { Q8. What preventive measures are used to control weeds, disease and } \\
\quad \text { insects/molluscs? }\end{array}$ & 1.70 & 0.1942 \\
Q9. What factors do you consider when deciding on your pest management plan? & 0.35 & 0.7067 \\
Q14. Membership of an agronomy / crop discussion group? & 0.06 & 0.9397 \\
\hline
\end{tabular}


Figure 1. Overall approach used to develop and validate the IPM metric, divided into seven tasks.

Figure 2. Distribution of sample by IPM score. 
Supplementary materials.

\section{Appendix 1: Best arable farming practice survey}

This survey is part of a wider study which aims to improve farmer awareness and adoption of Integrated Pest Management (IPM) in the UK and Ireland. IPM is widely regarded as offering benefits to farmers in their efforts to control pests, including reducing pollution risk and costs.

The study objectives will be achieved by:

1. collection of information (through this survey) on current IPM practices in arable farming;

2. analysis of this information to identify best practice; and

3. transfer of this knowledge back to farmers and advisors through various knowledge transfer activities, including publications in trade magazines.

The findings will be reported at a group level only i.e. data collected from individual growers, discussion groups, facilitators or advisors will not be published. This study is not concerned with, and does not collect data relating to, farm support payments, Cross Compliance activities or AgriEnvironment schemes. The survey should take between 10-15 minutes to complete and you should not need to consult farm records.

All data supplied will be treated in the strictest confidence, will be used solely for the purposes of this study, and will not be passed on to third parties. If you submit a completed survey form you can withdraw at any time. If you should wish to withdraw please contact me using the contact information provided on this letter. Please retain this letter for your records. This survey has passed all ethical clearance procedures at the co-ordinating institution.

Thank you for participating in our survey. 


\section{Best arable farming practice survey}

- $\quad$ Please answer the questions as accurately as you can. Good data is needed to provide reliable advice back to farmers and advisors.

- $\quad$ Please note that the term 'pests' relates to diseases, weeds and invertebrate pests (insects and molluscs). Similarly, 'pesticides' refers to fungicides, herbicides, insecticides and molluscicides.

- Please read question instructions carefully as the type of response required may vary from question to question.

- Please complete the survey in full.

1. How familiar are you with Integrated Pest Management (IPM)? Please tick one answer only.

Not at all familiar (if this answer, please move direct to Question 3.)

Somewhat unfamiliar

Moderately familiar

Familiar

Very familiar

2. Which of the following factors do you consider to be important components of IPM? Please tick one box in every row.

\begin{tabular}{|l|l|l|l|l|l|}
\hline & $\begin{array}{l}\text { Very } \\
\text { unimportant }\end{array}$ & $\begin{array}{l}\text { Not } \\
\text { important }\end{array}$ & $\begin{array}{l}\text { Neither } \\
\text { important } \\
\text { or } \\
\text { unimportant }\end{array}$ & $\begin{array}{l}\text { Fairly } \\
\text { Important }\end{array}$ & $\begin{array}{l}\text { Very } \\
\text { important }\end{array}$ \\
\hline $\begin{array}{l}\text { Preventative measures (hygiene practices such as } \\
\text { cleaning equipment, sourcing clean seed etc.) }\end{array}$ & & & & & \\
\hline $\begin{array}{l}\text { Biological control methods (growing competitive } \\
\text { crops, beetle banks etc.) }\end{array}$ & & & & & \\
\hline $\begin{array}{l}\text { Cultural control methods (altering drilling dates } \\
\text { to reduce disease, increasing seeding rate to } \\
\text { control weeds, rotating crops etc.) }\end{array}$ & & & & & \\
\hline $\begin{array}{l}\text { Monitoring and surveillance of insect pest, weed } \\
\text { and disease levels (crop walking, reacting to high } \\
\text { disease/pest pressure alerts etc.) }\end{array}$ & & & & & \\
\hline Minimum use of pesticides & & & & & \\
\hline
\end{tabular}

3. What proportion of your land is in continuous cereal production i.e. growing cereals on the same land for 5 or more consecutive years without growing a break crop (e.g. oilseed rape, beans, peas, grass)? Please circle the relevant proportion below.

\begin{tabular}{|l|l|l|l|l|}
\hline None & $1-25 \%$ & $26-50 \%$ & $51-75 \%$ & $76-100 \%$ \\
\hline
\end{tabular}

4. Why do you practice continuous cereal production? More than one answer may be provided.

I don't practice it

Land unsuitable for other crops

Climate unsuitable for other crops

No access to machinery/equipment/storage facilities required to grow non-cereal crops

Greater risks associated with growing different crops

End-market requirements 
6. Please indicate your tillage practice. More than one answer may be provided.
Regular ploughing
Direct drilling (no tillage)
Strip tillage
Reduced (minimum) tillage
Rotational ploughing (every few years)

7. What influences your choice of cereal or oilseed variety grown? Please tick the factors you consider most important for each crop you grow. More than one answer may be provided.

\begin{tabular}{|l|l|}
\hline Recommended lists (where available) & \\
\hline Availability of seed & \\
\hline Advisor recommendation & \\
\hline End-market & \\
\hline Disease resistance & \\
\hline Weed competitiveness & \\
\hline Insect pest resistance & \\
\hline Abiotic stress resistance (e.g. drought/flooding/cold tolerance) & \\
\hline Yield potential & \\
\hline Quality potential & \\
\hline Consistency of performance & \\
\hline
\end{tabular}

8. Which preventative measures do you currently employ to control the introduction and spread of pests on your farm? Please tick all the boxes below that apply.

\section{a) To control weeds}

Stale seedbeds

Full inversion ploughing to control low dormancy weeds

Min-till to control high dormancy weeds

Pre-emergence herbicide applications

Spot spraying weeds (if necessary)

Hand rogueing/hoeing weeds

Manage headlands differently to remainder of field

Fields with high weed levels are harvested last 


\section{b) To control disease}

Grow resistant varieties

Use certified seed

Test non-certified seed and treat if required

Regularly test soils for soil borne pathogens

Use seed treatments to control disease

Crop inspections, please indicate frequency; once or twice per (please circle one of the following options):

\begin{tabular}{|l|l|l|}
\hline week & month & season \\
\hline
\end{tabular}

\section{c) To control insects, nematodes and molluscs}

Encourage beneficial insects through planting habitat

Avoid broad spectrum insecticides

Use seed treatments

Preparations for control of molluscs e.g. avoiding direct drilling or preparation of fine seed bed

Regularly monitor above ground pest populations

Set action thresholds

Regularly test soils for nematodes

Regularly test soils for insect pests

Frequently clean harvesting and storage equipment

Crop inspections, please indicate frequency; once or twice per (please circle one of the following options):

\begin{tabular}{|l|l|l|}
\hline week & month & season
\end{tabular}

\section{What factors do you consider when deciding on a pest management plan at the start of the} season?

Please tick those that apply.

I don't use pest management plans

Crop walking data from last season, used to assess the performance of various control measures

Technical research on pesticide product efficacy

Weed maps, created and monitored for changes between seasons

Yield maps, used to identify areas requiring specific attention

Cost-benefit analysis of management options

End-market requirements

Variety resistance

Soil borne pathogens

Position in rotation

Anti-resistance strategies

None of the above

Other (please specify)

10. What factors influence your decision to adjust your spray programme (e.g. changes in timings, rates, products) throughout the season? Please answer every row by ticking in one of the columns. 
12. How valuable are the following sources of pest (weeds, diseases, insects or molluscs) management advice?

Please rank the top 3 sources of pest advice starting with 1 being the most valuable. After listing the top 3, please leave the rest blank.

\begin{tabular}{|l|l|}
\hline Open days/crop walks & Rank top 3 sources \\
\hline Farmer discussion groups & \\
\hline Other farmers (not including discussion groups) & \\
\hline Independent agronomist & \\
\hline Chemical company representative & \\
\hline Merchant agronomist & \\
\hline Contractors & \\
\hline Past experience & \\
\hline Farming press & \\
\hline Other (please specify) & \\
\hline
\end{tabular}

13. Which of the following statements best describes your relationship with your main crop protection advisor? Please tick one only.

I rely on them and act on their suggestions

I tell them what I want from them and they respond to meet my wishes

We decide on the pest management strategy together

I listen to their advice but will always consult other sources of information

I listen to their advice but adjust if needed when in the field

I don't use an advisor

14. Are you a member of an agronomy or crop discussion group? Please tick. 
Yes

No

If Yes, please specify

15. What is your position on the farm? More than one box may be ticked.
Owner
Tenant
Farm worker
Contractor

16. How much land do you farm or manage?

Total area: hectares:

Of which - arable hectares

grassland hectares

rough grazing

hectares

fallow hectares

biodiversity scheme hectares

How much of the area farmed is rented/leased: hectares

How much of the area farmed is shared: hectares

17. Which description best fits your farming type? Please tick one box only.

Predominantly arable

Predominantly livestock

Mixed

Horticulture

18. Your age. Please circle.

\begin{tabular}{|l|l|l|l|l|}
\hline $20-30$ & $31-40$ & $41-50$ & $51-60$ & 61 and over \\
\hline
\end{tabular}

19. Which qualifications have you achieved? Please tick one only.

Certificate in farming (e.g. BASIS)

O levels/GCSEs/Junior certificate

A levels/Leaving certificate

Diploma

Bachelor's Degree

Higher degree (Master's degree/PhD) 
20. Does the main decision-maker of the farm business have an off-farm income source? Please tick.

Yes

No

21. Is there a successor identified to take over the farm business? Please tick.
Yes
No
Uncertain at present

22. Are you involved in a scheme that promotes biodiversity e.g. Countryside Stewardship, LEAF, AEOS, GLAS? Please tick.
Yes
No

Thank you very much for your help in our research.

The information you have provided will be treated in the strictest confidence by us. 


\section{Appendix 2: Guidance for stakeholders attending the workshop designed to create an initial weighting system for IPM adoption.}

\section{Best arable farming practice survey}

This survey is part of a wider study which aims to improve farmer awareness and adoption of Integrated Pest Management (IPM) in the UK and Ireland. IPM is widely regarded as offering benefits to farmers in their efforts to control pests, including reducing pollution risk and costs.

The study objectives will be achieved by:

1. collection of information (through this survey) on current IPM practices in arable farming;

2. analysis of this information to identify best practice; and

3. transfer of this knowledge back to farmers and advisors through various knowledge transfer activities, including publications in trade magazines.

The findings will be reported at a group level only i.e. data collected from individual growers, discussion groups, facilitators or advisors will not be published. This study is not concerned with, and does not collect data relating to, farm support payments, Cross Compliance activities or AgriEnvironment schemes. The survey should take between 10-15 minutes to complete and you should not need to consult farm records.

All data supplied will be treated in the strictest confidence, will be used solely for the purposes of this study, and will not be passed on to third parties. If you submit a completed survey form you can withdraw at any time. If you should wish to withdraw please contact me using the contact information provided on this letter. Please retain this letter for your records. This survey has passed all ethical clearance procedures at the co-ordinating institution.

\section{Scoring system}

Today we'll be collectively creating a point scoring system to quantify IPM adoption. The approach will involve weighting questions according to how important we decide they are for IPM. The method will involve allocating a total of 100 points over the questions we've pre-selected to contribute towards the point scoring system. These questions $(Q 3,5,7,8,9,14)$ are highlighted in the survey.

- For Q3, 5, 7, 9, and 14 we will discuss the importance of the options, come to a consensus and rate them on a $\underline{1-5 \text { scale. }}$.

- $\underline{\text { Q8 }}$ is probably the most important question in the set as it captures the IPM control measures actually being undertaken. For this question we will weight the individual control measures for importance using a weighting scale that really allows individual measures to stand out. So, the weighting for Q8 options will involve allocating 100 points over all the measures.

Thank you for your contribution to this project. 


\section{Appendix 3: Stakeholder guidance letter for consultation on scoring system for assessing farmers' IPM adoption}

\section{Best arable farming practice study}

In early 2017, researchers from four institutions surveyed arable farmers in the UK and Ireland. This survey collected information on current Integrated Pest Management (IPM) practices in arable farming. To facilitate our analysis of the responses we would like you to help us identify what best IPM practice is.

At a recent workshop, stakeholders were asked to score each survey question (and options within questions) relating to IPM practice. By creating an IPM scoring system, we can apply these scores to the survey responses and, in this way, rate each respondent in terms of their IPM activity. We need your help in validating the proposed scoring system. Below is a worked example showing what we want you to do.

At the workshop, agronomic and IPM issues relating to key survey questions were discussed in detail to capture the contribution (\%) of each to the overall IPM score. Separate scores are applied on a 1 to 5 scale (from 1 being not at all important to 5 being very important) to capture the relative importance of specific management activities within each question. Initial scores for each possible answer were suggested, and were then agreed upon during the discussions. If a clear consensus was not reached, a vote decided the final score. Survey participants' responses to each question will determine what share (\%) of the maximum contribution for the question makes to the IPM score.

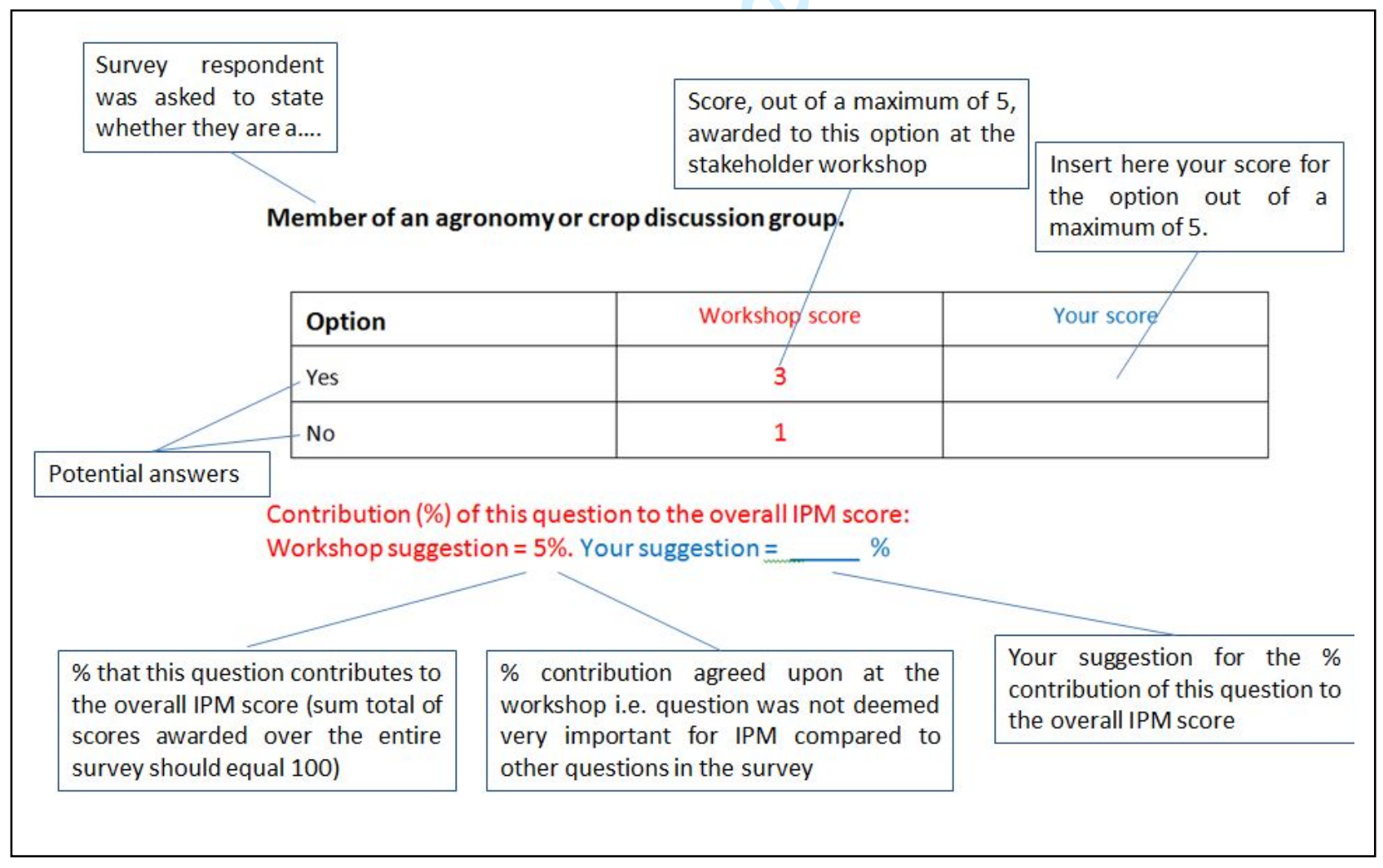


To validate the proposed scoring system, we are consulting stakeholders to ask them to modify our scores if they wish. We would appreciate it if you could take the time to consider the questions attached, together with the scores given to each at the workshop. Please examine each question and all possible answers and adjust the scores as you see fit. Once you are finished, please send the document back to us.

This is part of a wider study aimed at improving farmer awareness and rates of adoption of IPM. Once we have identified best practice, we will communicate with farmers and advisors through various knowledge transfer activities. Thank you for your contribution to this project. Your responses will remain entirely confidential and individual answers will not be identified in any report we may produce.

Dr Henry Creissen Henry.creissen@sruc.ac.uk 


\section{Stakeholder consultation on scoring system for assessing farmers' IPM $\underline{\text { adoption }}$}

NB: In this file the final weights for sub-elements within each question have been inserted in the columns labelled 'Your score', which were of course blank when the file was distributed to the stakeholder panel.

\section{Instructions:}

- The original scores from the stakeholder workshop are shown in red. Please insert your score in the blue columns next to the workshop scores. Please indicate the relative contribution of each question to the final IPM score which should total to $100 \%$ for all questions combined.

- Please rate each option within each question on a 1 to 5 scale with 1 being not at all important for IPM, to 5 being very important for IPM.

\section{Key questions:}

3. Proportion of land in continuous cereal production i.e. cereals on the same land for 5 or more years without a break crop (e.g. OSR, beans, grass)?

\begin{tabular}{|l|c|c|}
\hline Option & Workshop score & Your score \\
\hline None & 5 & 4.93 \\
\hline $1-25 \%$ & 5 & 4.46 \\
\hline $26-50 \%$ & 3 & 2.98 \\
\hline $51-75 \%$ & 2 & 1.98 \\
\hline $77-100 \%$ & 1 & 1.13 \\
\hline
\end{tabular}

Contribution (\%) of this question to the overall IPM score:

Workshop suggestion $=10 \%$. Your suggestion $=11.51 \%$

5. If you typically use an arable rotation, why do you do this?

\begin{tabular}{|l|c|c|c|c|c|c|c|c|c|c|}
\hline & \multicolumn{2}{|l|}{$\begin{array}{l}\text { Strongly } \\
\text { disagree }\end{array}$} & \multicolumn{2}{l|}{ Disagree } & \multicolumn{2}{l|}{$\begin{array}{l}\text { Neither agree } \\
\text { or disagree }\end{array}$} & \multicolumn{2}{l|}{ Agree } & \multicolumn{2}{l|}{ Strongly agree } \\
\hline Option & $\begin{array}{c}\text { Work- } \\
\text { shop } \\
\text { score }\end{array}$ & $\begin{array}{c}\text { Your } \\
\text { score }\end{array}$ & $\begin{array}{c}\text { Work- } \\
\text { shop } \\
\text { score }\end{array}$ & $\begin{array}{c}\text { Your } \\
\text { score }\end{array}$ & $\begin{array}{c}\text { Work- } \\
\text { shop } \\
\text { score }\end{array}$ & $\begin{array}{c}\text { Your } \\
\text { score }\end{array}$ & $\begin{array}{c}\text { Work- } \\
\text { shop } \\
\text { score }\end{array}$ & $\begin{array}{c}\text { Your } \\
\text { score }\end{array}$ & $\begin{array}{c}\text { Work- } \\
\text { shop } \\
\text { score }\end{array}$ & $\begin{array}{c}\text { Your } \\
\text { score }\end{array}$ \\
\hline To control weeds & 1 & 0.87 & 2 & 1.61 & 3 & 2.39 & 4 & 3.26 & 5 & 4.13 \\
\hline To control disease & 1 & 0.95 & 2 & 1.63 & 3 & 2.39 & 4 & 3.29 & 5 & 4.13 \\
\hline $\begin{array}{l}\text { To control insect } \\
\text { pests }\end{array}$ & 1 & 0.92 & 2 & 1.63 & 3 & 2.39 & 4 & 3.18 & 5 & 4.03 \\
\hline $\begin{array}{l}\text { To improve and } \\
\text { maintain soil } \\
\text { structure and } \\
\text { fertility }\end{array}$ & 1 & 0.97 & 2 & 1.63 & 3 & 2.45 & 4 & 3.29 & 5 & 4.15 \\
\hline $\begin{array}{l}\text { To spread financial } \\
\text { risks }\end{array}$ & 5 & 3.34 & 4 & 2.89 & 3 & 2.32 & 2 & 1.47 & 1 & 1.18 \\
\hline $\begin{array}{l}\text { Largely because } \\
\text { it’s necessary to } \\
\text { comply with } \\
\text { regulations }\end{array}$ & 5 & 3.53 & 4 & 2.92 & 3 & 2.24 & 2 & 1.55 & 1 & 1.18 \\
\hline
\end{tabular}


Contribution (\%) of this question to the overall IPM score: Workshop suggestion $=10 \%$. Your suggestion $=11.84 \%$

\section{Influences on choice of cereal or oilseed variety grown?}

\begin{tabular}{|l|c|c|}
\hline Option & Workshop score & Your score \\
\hline Recommended lists (where available) & 5 & 4.41 \\
\hline Availability of seed & 1 & 1.67 \\
\hline Advisor recommendation & 2 & 3.09 \\
\hline End-market & 1 & 2.48 \\
\hline Disease resistance & 5 & 4.59 \\
\hline Weed competitiveness & 2 & 2.59 \\
\hline Insect pest resistance & 2 & 2.78 \\
\hline Abiotic stress resistance (e.g. drought/flooding/cold tolerance) & 2 & 2.22 \\
\hline Yield potential & 1 & 2.65 \\
\hline Quality potential & 2 & 2.80 \\
\hline Consistency of performance & 3 & 3.52 \\
\hline
\end{tabular}

Contribution ( $\%$ ) of this question to the overall IPM score:

Workshop suggestion $=5 \%$. Your suggestion $=8.80 \%$

\section{Preventative measures currently employed to control the introduction and spread of pests on their farms?}

a) To control weeds

\begin{tabular}{|l|c|c|}
\hline Option & Workshop score & Your score \\
\hline Stale seedbeds & 5 & 4.57 \\
\hline Full inversion ploughing to control low dormancy weeds & 5 & 4.24 \\
\hline Min-till to control high dormancy weeds & 5 & 4.52 \\
\hline Pre-emergence herbicide applications & 3 & 4.65 \\
\hline Spot spraying weeds (if necessary) & 5 & 4.39 \\
\hline Hand rogueing/hoeing weeds & 5 & 4.33 \\
\hline Manage headlands differently to remainder of field & 5 & 3.57 \\
\hline Fields with high weed levels are harvested last & 4 & 4.52 \\
\hline Weekly crop inspections & 5 & 2.72 \\
\hline Monthly crop inspections & 3 & 1.09 \\
\hline A single crop inspection per season & 1 & \\
\hline
\end{tabular}


b) To control disease

\begin{tabular}{|l|c|c|}
\hline Option & Workshop score & Your score \\
\hline Grow resistant varieties & 5 & 4.85 \\
\hline Use certified seed & 5 & 4.20 \\
\hline Test non-certified seed and treat if required & 5 & 4.70 \\
\hline Regularly test soils for soil borne pathogens & 2 & 4.63 \\
\hline Use seed treatments to control disease & 5 & 4.67 \\
\hline Weekly crop inspections & 5 & 3.24 \\
\hline Monthly crop inspections & 4 & 1.02 \\
\hline A single crop inspection per season & 1 & \\
\hline
\end{tabular}

c) To control insects, nematodes and molluscs

\begin{tabular}{|l|c|c|}
\hline Option & Workshop score & Your score \\
\hline Encourage beneficial insects through planting habitat & 4 & 3.93 \\
\hline Avoid broad spectrum insecticides & 5 & 4.57 \\
\hline Use seed treatments & 5 & 4.70 \\
\hline $\begin{array}{l}\text { Preparations for control of molluscs e.g. avoiding direct drilling } \\
\text { or preparation of fine seed bed }\end{array}$ & 5 & 4.87 \\
\hline Regularly monitor above ground pest populations & 5 & 4.61 \\
\hline Set action thresholds & 5 & 3.04 \\
\hline Regularly test soils for nematodes & 3 & 1.63 \\
\hline Regularly test soils for insect pests & 1 & 4.02 \\
\hline Frequently clean harvesting and storage equipment & 5 & 4.61 \\
\hline Weekly crop inspections & 5 & 3.15 \\
\hline Monthly crop inspections & 5 & \\
\hline A single crop inspection per season & 5 & \\
\hline
\end{tabular}

Contribution (\%) of this question to the overall IPM score:

Workshop suggestion $=55 \%$. Your suggestion $=47.13 \%$ 
9. Factors considered when deciding on a pest management plan at the start of the season.

\begin{tabular}{|l|c|c|}
\hline Option & Workshop score & Your score \\
\hline I don't use pest management plans & 0 & 0.48 \\
\hline $\begin{array}{l}\text { Crop walking data from last season, used to assess the } \\
\text { performance of various control measures }\end{array}$ & 4 & 4.52 \\
\hline Technical research on pesticide product efficacy & 4 & 4.35 \\
\hline $\begin{array}{l}\text { Weed maps, created and monitored for changes between } \\
\text { seasons }\end{array}$ & 4 & 3.98 \\
\hline Yield maps, used to identify areas requiring specific attention & 2 & 3.96 \\
\hline Cost-benefit analysis of management options & 2 & 3.02 \\
\hline End-market requirements & 4 & 4.46 \\
\hline Variety resistance & 5 & 4.50 \\
\hline Soil borne pathogens & 5 & 4.83 \\
\hline Position in rotation & 5 & 4.89 \\
\hline Anti-resistance strategies & -5 & -1.11 \\
\hline None of the above & & 5 \\
\hline
\end{tabular}

Contribution (\%) of this question to the overall IPM score:

Workshop suggestion $=15 \%$. Your suggestion $=15.30 \%$

\section{Member of an agronomy or crop discussion group.}

\begin{tabular}{|l|c|c|}
\hline Option & Workshop score & Your score \\
\hline Yes & 3 & 3.39 \\
\hline No & 1 & 0.87 \\
\hline
\end{tabular}

Contribution (\%) of this question to the overall IPM score:

Workshop suggestion $=5 \%$. Your suggestion $=5.85 \%$ 


\section{Appendix 4:}

For survey data input file see separate Excel file.

\section{Appendix 5: Normal probability-probability plot of the data}

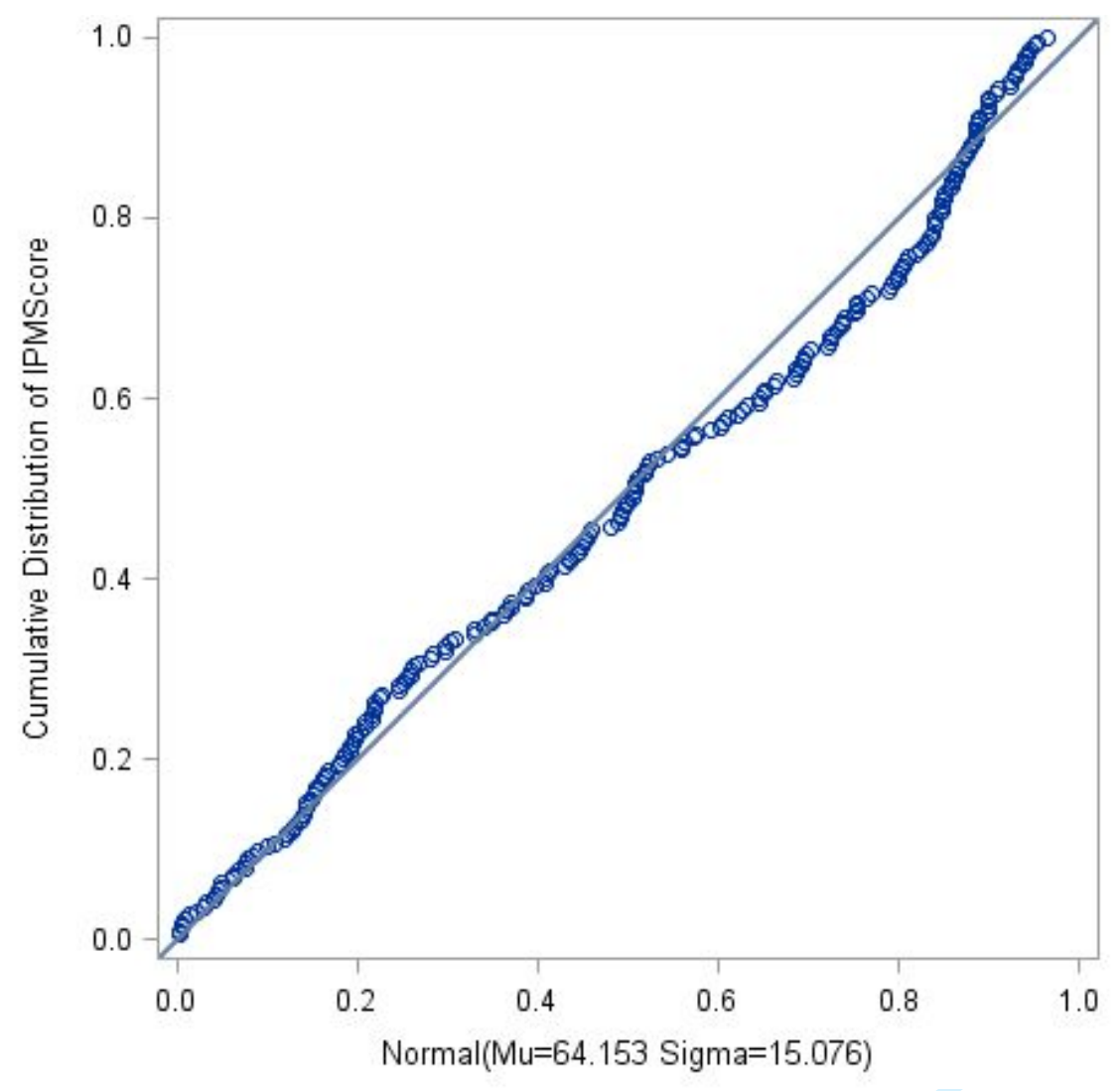

Figure shows a Normal probability-probability plot indicating that the distribution of scores over the IPM metric key variables was close to normal. 